\title{
Computed tomography- osteoabsorptiometry: a method of assessing the mechanical condition of the major joints in a living subject
}

\author{
M Müller-Gerbl ${ }^{1}$ \\ R Putz ${ }^{1}$ \\ N Hodapp ${ }^{2}$ \\ E Schulte ${ }^{1}$ \\ B Wimmer ${ }^{3}$ \\ 'Anatomische Anstalt der Universität München, ${ }^{2}$ Radiologisches Institut, Abteilung Strahlen- \\ therapie der Universität Freiburg, and ${ }^{3}$ Radiologisches Insitut, Abteilung Röntgendiagnostik der \\ Universität Freiburg, FRG
}

\begin{abstract}
Summary
A method of making a visual display of subchondral mineralization in the major synovial joints is described. Unlike existing procedures, it can be used on the living subject. A modified application of computed tomography-densitometry, computed tomography-osteoabsorptiometry makes it possible to explore the mechanical adaptability to the prevailing mechanical force. This claim is based upon the comparison of information obtained from 20 anatomical specimens with CT. osteoabsorptiometry and $\mathrm{x}$-ray densitometry of sections; both methods yielding virtually identical results. The distribution of the subchondral density was then expressed as a map of the articular surface with the aid of an image analyser. This method can make a useful contribution to basic clinical research, as well as providing a diagnostic technique which can also be used for observing progress after a corrective osteotomy or any other procedure causing a change in mechanical function. Examples of its use on living patients are given.
\end{abstract}

\section{Relevance}

Computed tomography-osteoabsorptiometry offers a method for assessing, during life, the individual stresses acting on a joint which can be applied in many fields, both in basic research and in hospital practice.

Key words: CT-osteoabsorptiometry, subchondral mineralization, biomechanics, functional adaptation, $x$-ray densitometry

\section{Introduction}

The measurement of subchondral mineralization is of decisive importance in assessing the functional adapta-

Received: 7 August 1989

Accepted: 21 May 1990

Correspondence and reprint requests to: Dr $\mathrm{M}$ Müller-Gerbl, Anatomische Anstalt I, Pettenkoferstr.11, D-8000 München 21, FRG

(C) 1990 Butterworth-Heinemann Ltd 0268-0033/90/040193-06 tion of bony tissue to various individual stresses. In his seventh contribution to functional anatomy and the histogenesis ('Kausale Histogenese') of the skeletal system, Pauwels ${ }^{1}$ concluded that the local density of the spongy bone closely follows the distribution of the applied load in the photoelastic model. His reports are based on an estimated comparison between the structural density of an $x$-ray film of the proximal shaft of the femur and the stress values derived from the experimental model. His corresponding work ${ }^{2}$ on the elbow joint 
showed a similar relationship in the ulna between subchondral bone density and the magnitude of the applied stress, leading him to the concept of a materialized field of stress ('verkörpertes Spannungsfeld'). A similar conclusion was reached by Kummer ${ }^{3}$, and both authors assumed that the loading history of the bone is in some way represented by the $\mathrm{x}$-ray density.

$\mathrm{Knief}^{4,5}$ quantitatively related the distribution of bone density in the upper end of the femur to its $\mathrm{x}$-ray opacity, and showed at the same time that it closely approximates to the distribution of strain in the photoelastic model. Schmitt ${ }^{6}$, Amtmann and Schmitt ${ }^{7}$ and Amtmann ${ }^{8}$ finally demonstrated a direct correlation between $\mathrm{x}$-ray density and the strength of the tissue. Konermann ${ }^{9,10}$ developed a photographic method in which $\mathrm{x}$-ray regions of 'equidensity' are represented by contour lines. The density distribution can be read directly from these superimposed pictures, and represented quantitatively by layered aluminium strips. Schleicher and his co-workers $^{11}$ carried the equidensity method further forward by scanning the picture mechanically and measuring the degree of opacity with an image analysing system.

The major disadvantage of all these methods lies in the fact that the measurement of bony density on an $x$ ray plate can only be carried out on sectioned specimens. We therefore sought a method of determining the density distribution of the subchondral bone with computed tomography (CT) x-ray osteoabsorptiometry, which could be used on the living and could therefore be employed in clinical practice.

\section{Materials and methods}

1. Anatomical specimens for the 'compare and contrast' study were taken from the dissecting room of the Anatomisches Institut, Freiburg and München, and included 10 knee-joints and 10 shoulder-joints.

2. Computer tomograms were obtained of:

(a) the shoulder-joint in 15 normal subjects between the ages of 23-46 yr (8 males and 7 females, and of $12 \mathrm{pa}$ tients suffering from various diseases of the shoulderjoint, six of either sex, aged 34-56);

(b) the femoropatellar-joint in 7 males and 5 females, aged 16-65 yr, with no history of pain in the knee. Computer tomograms were made from each of these specimens at intervals of $2 \mathrm{~mm}$ with a Siemens Somatom DR-H.

\section{CT-osteoabsorptiometry in terms of Hounsfield units}

The method described in the following is supposed to reflect the relative differences within the subchondral joint surface. We called this method CT-osteoabsorptiometry to emphasize the difference from the conventional methods of CT-densitometry used in the diagnosis of osteoporosis, which measure the mean mineral content of bone in absolute values $\left(\mathrm{g} \mathrm{cm}^{-3}\right)$ of a region of interest including trabecular bone.

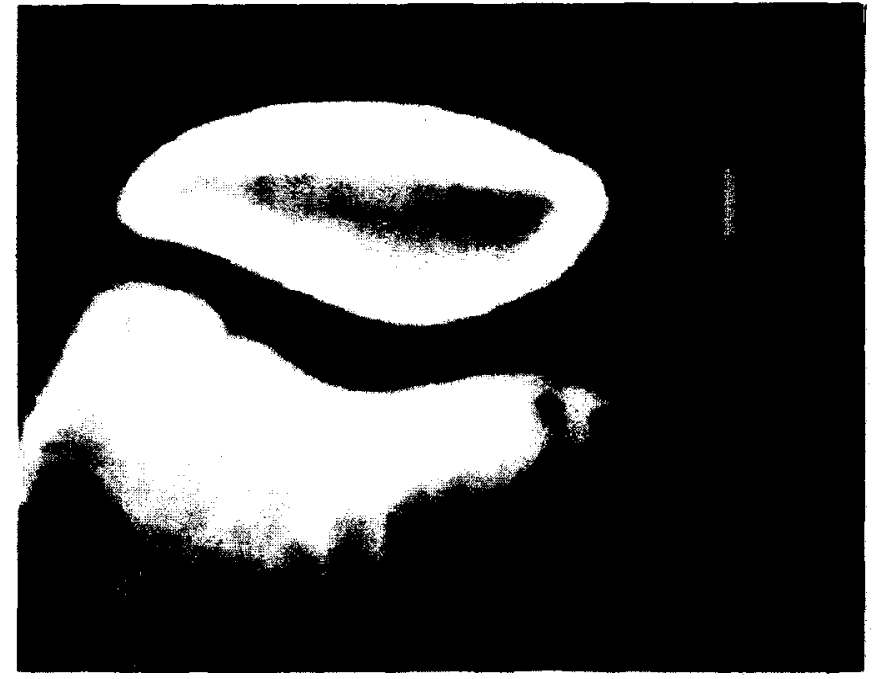

a

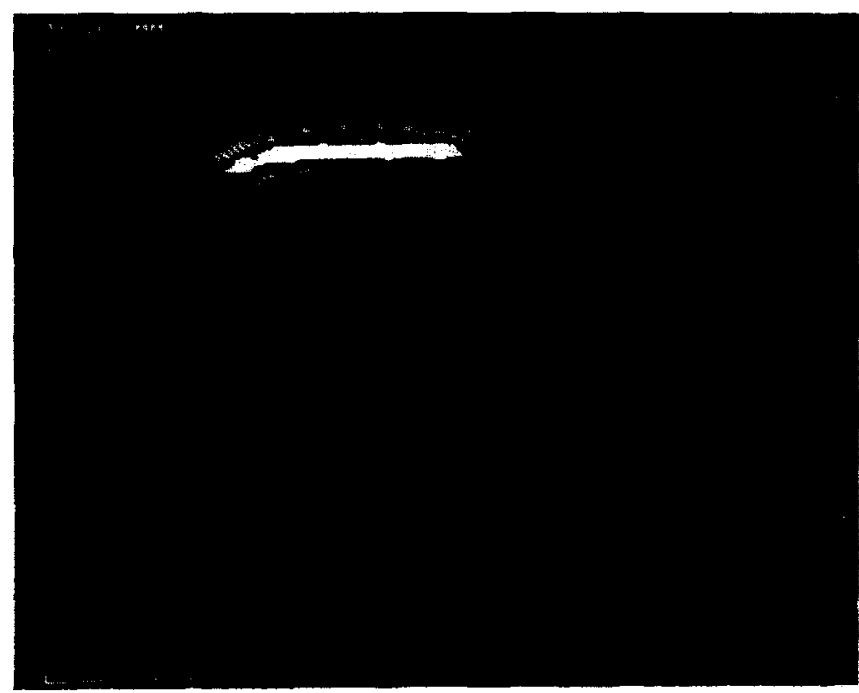

b

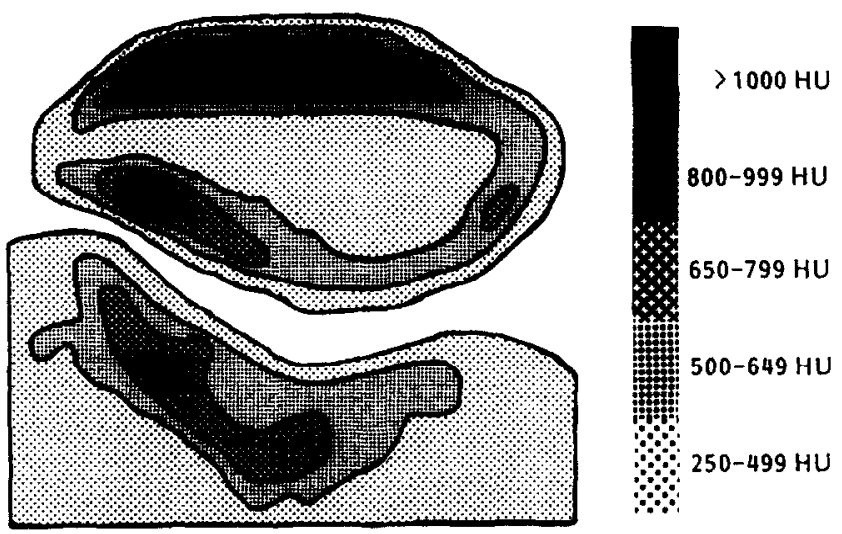

c

Figure 1. CT-osteoabsorptiometry of right femoropatellar joint. a, Axial CT section; $b$, isodensities in subchondral region of articular surface of patella and corresponding surface of temur; c, diagram of opposing articular surfaces of femoropatellar joint showing regions of different density (copied from false-colour display).

The tomograms are processed in a Siemens Evados radiotherapy planning computer. The EVAl software is first used to modify and enlarge the scans until the region of interest occupies the entire screen (Figure 1a), and the resulting data set is then converted into a form which 

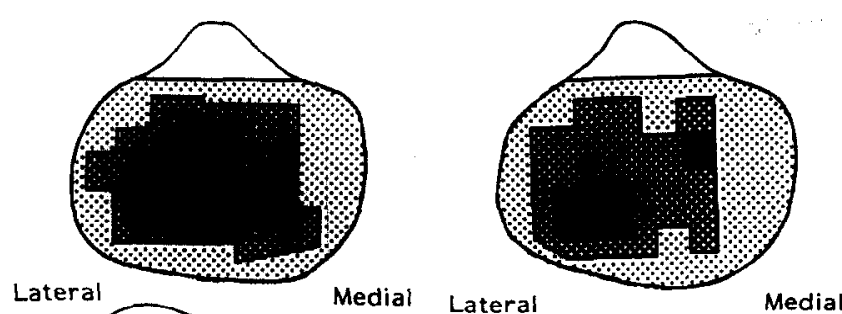

8
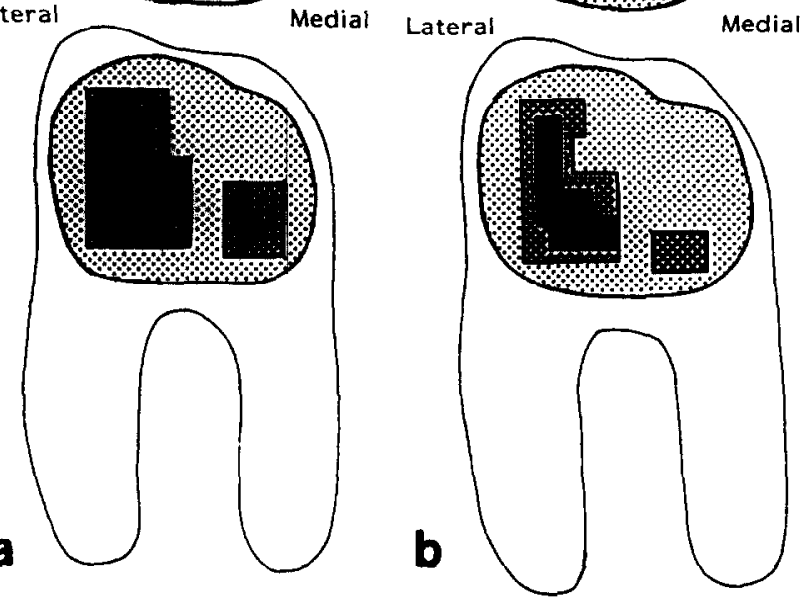

Figure 2. Patellar (above) and femoral articular surfaces of femoropatellar joint (below) showing surface distribution of subchondral mineralization. a, Results obtained with $x$-ray densitometry; b, results obtained with CT-osteoabsorptiometry.

the SIDOS-TELE software can handle. For our work, six density ranges were selected and expressed in Hounsfield units (HU): <250; 250-499 HU; 500-649 $\mathrm{HU} ; 650-799 \mathrm{HU} ; 800-999 \mathrm{HU}$; and $>1000 \mathrm{HU}$.

The sIDOS-TELE subroutine is then able to display the 'isodensits' (contour lines joining regions of equal density) (Figure 1b).

The resulting pictures are then subjected to image analysis with an IBAS 2000 calculator (Zeiss, Oberkochen), regions of equal density being displayed in the same colour (Figure 1c).

To arrive at the absorption pattern over the entire joint surface the classified Hounsfield values were, in each CT section, calculated along a line $1.5 \mathrm{~mm}$ below the joint surface and displayed as a two-dimensional surface map (Figure 2).

Depending on the enlargement of the original tomogram sections, the final resolutions lie between $0 \cdot 25-0 \cdot 8$ $\mathrm{mm}$. (The method is described in detail elsewhere ${ }^{12}$ ).

\section{$X$-ray densitometry}

The fresh specimens were finally sawn into parallel sections $2 \mathrm{~mm}$ thick. X-ray films were made from these sections, and pictures directly constructed in which regions of equal density were again represented by the same colour. As with the CT-densitometry already described, a further development of this method (originally due to Schleicher and his co-workers ${ }^{11}$ ) enabled us to make a similar surface map of the subchondral mineralization at a depth of $1 \mathrm{~mm}$. In this way we were able to obtain a density map of the joint surface by two completely distinct methods.

\section{Results}

Comparison of the results obtained by each method, $\mathrm{x}$-ray densitometry and CT-osteoabsorptiometry, produced virtually identical pictures of the distribution pattern of subchondral bone density for all specimens, both in the individual sections and in the maps of the entire joint surface.

Systematic comparison of the corresponding single sections obtained by $\mathrm{x}$-ray densitometry and CT-osteoabsorptiometry respectively showed that an average of $81.7 \%$ of the pixels were of the same density level (at five selected stages), and that in the resulting image the same coordinates appeared. A difference of 1 degree of shading in the image was shown by $8.4 \%$ of the pixels, and a difference of 2 degrees of shading by $9.9 \%$.

By comparing directly the results obtained by the two methods allowed, for each joint surface, a "compare and contrast' study of the maps can be made. In examples showing the femoropatellar joint (Figure 2), or the glenoid cavity (Figure 3), the surface maps obtained by $\mathrm{x}$-ray densitometry and CT-osteoabsorptiometry appear at first glance to be identical. A similar agreement between the two methods was found without exception in every one of the specimens examined.

Corresponding surface maps of living subjects for the scapular element of the shoulder-joint are seen in Figure 4. Figure 4a is taken from a normal subject in whom the greatest density is located in the central part of the glenoid cavity. In Figure $4 b$ and $c$, on the other hand, maximum mineralization was found peripherally. The first of these is taken from a $37 \mathrm{yr}$-old patient with recurrent dislocation of the shoulder-joint, the second from a $46 \mathrm{yr}$-old man with instability of the same joint. In 10 of 12 patients the points of maximum density were found peripherally.

Beneath the articular cartilage of the patella, the points of maximum subchondral bone density are constantly found in the proximal part of the lateral joint surface (Figure 5). At the periphery, the density values

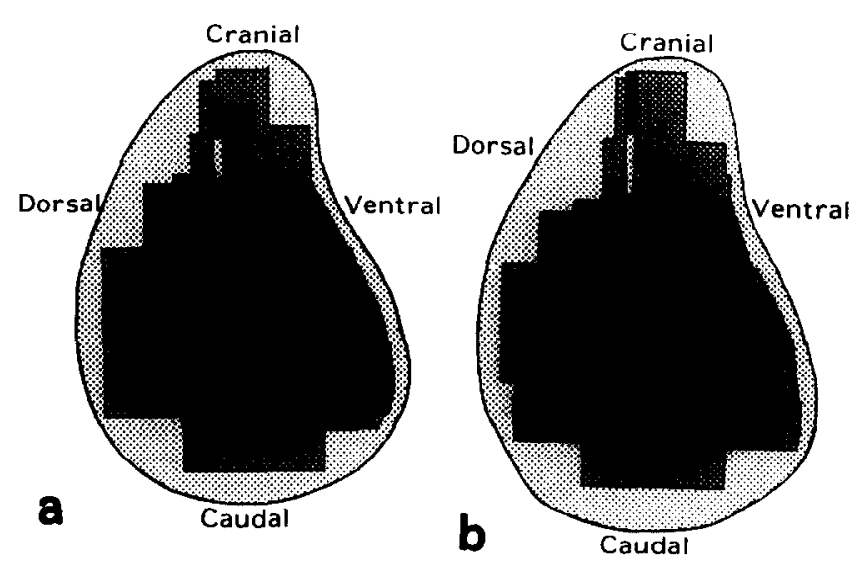

Figure 3. Lateral view of glenoid cavity showing surtace distribution of subchondral mineralization. a, Results obtained with $x$-ray densitometry $b$, results obtained with CT-osteoabsorptiometry. 

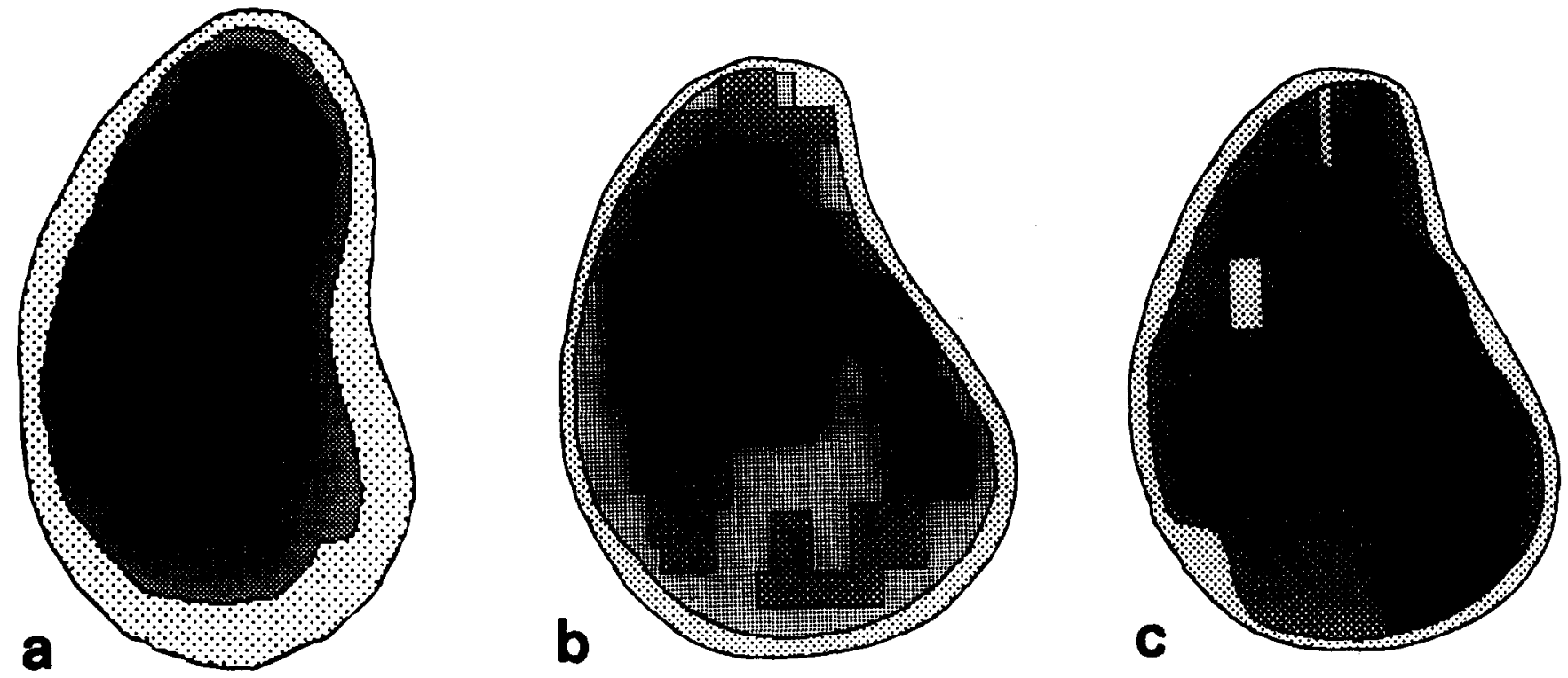

Figure 4. Lateral view of shoulder-joint of living subject showing surface distribution of subchondral mineralization obtained with CT-osteoabsorptiometry. a, Normal subject; b, 37 yr-old male with recurrent dislocation of shoulder-joint; c, 45 yr-old male with long term instability of shoulder-joint.

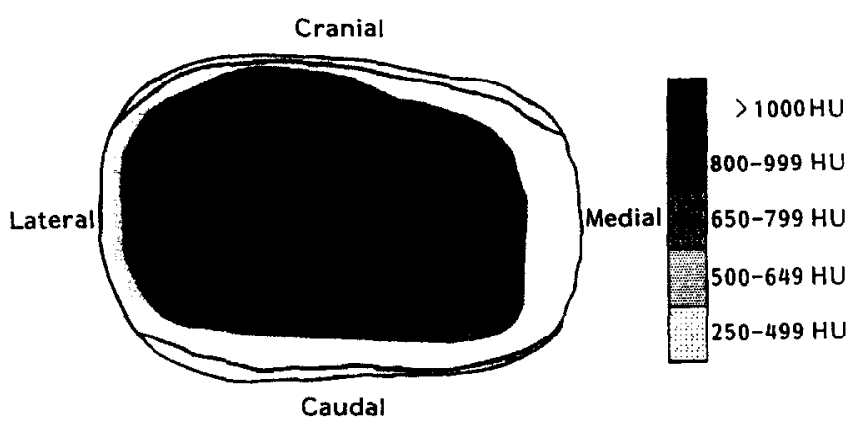

Figure 5. Posterior view of articular surface of patella showing characteristic distribution pattern of subchondral bone density with highest values appearing laterally.

fall away rapidly in a lateral direction, and more gently in a medial direction.

The points of maximum density on the patellar surface of the femur are on average 150-300 HU lower than those of the corresponding surface of the patella.

\section{Discussion}

Since all these comparisons show, without exception, significant agreement in the density distribution of the subchondral bony tissue of the joint, we feel justified in accepting CT-osteoabsorptiometry as a reliable method for assessing the distribution of subchondral mineralization. Moreover, it is possible to compare results obtained from $x$-ray densitometry, including further work on several joints ${ }^{3,13-18}$ directly with results obtained by CT-osteoabsorptiometry. Admittedly, there are certain characteristics associated with the CT-osteoabsorptiometry of each joint which call forth some reservations. The 'partial volume effect' in particular can lead to false results, and should be taken into account when dealing with the anatomical sections. During construction of the CT images, each volumetric element or 'voxel' is treated as though it were structurally homogeneous; and since regions of different density within the same voxel are recorded as having the same (average) value, an artificial assessment of the structural density can follow. This phenomenon is of importance when representing borderline regions, where the surrounding tissue will of necessity be allotted lower values. It is also necessary to remember that values given in terms of Hounsfield units only provide exact data on local mineralization when they can be related to a reference standard, such as that used for the diagnosis of osteoporosis. A detailed account of the sources of errors will be found in MüllerGerbl et at ${ }^{12}$. But, provided that the possibility of such errors is borne in mind, CT-osteoabsorptiometry is a method which enjoys the great advantage of being applicable to living subjects. What is more, the $x$-ray dosage involved during the use of the new apparatus is tolerable. As Cann ${ }^{19}$ has stated 'the radiation exposure of a single CT examination is comparable to less than a one-month exposure to natural radiation or less than the exposure for a single chest radiograph'.

Since x-ray densitometry and histological examination can only be used to assess the adaptation of bone to mechanical stress in postmortem specimens, only the end result of this stress can be explored by these methods. This means, of course, that such investigations can only be carried out in man by using postmortem, forensic or dissecting-room specimens, and this excludes any possibility of selecting subjects for age.

CT-osteoabsorptiometry allows the investigator to select at will normal subjects, or people who are, for professional reasons, exposed to abnormal stress (e.g. athletes), and to observe them over long periods of time. 
It is also true that the functional adaptation of bone to repeated and long-term changes in the load for example, months of immobilization followed by normal activity, or severe overloading, cannot be investigated by normal methods in animals, since death of the animal is an unavoidable precondition for exact quantitative study of the tissue. These difficulties also apply to progressive observation of the changes, either in planned repeatable animal experiments or in patients subjected to abnormal loads following a displacement osteotomy, for example.

The theoretical justification for our views lies in the fact that CT-osteoabsorptiometry can be used for diagnosing the causes of painful joints in cases where other methods such as arthroscopy, arthrography, straight $\mathrm{x}$ rays, CT or magnetic resonance (MR) reveal no basis for the condition. The results obtained from the shoulderjoint alone suggest that instability or repeated dislocation of this joint is accompanied by abnormal, eccentric stress upon the glenoid cup rather than, as is normally the case, upon the centre of the articular surface. It is surely possible that abnormal stress of this kind can eventually cause many different kinds of pain in a joint.

The results obtained from the femoropatellar joint agree well with the $x$-ray densitometric and photoelastic findings ${ }^{20,21}$. Against the background of biomechanical calculations $^{22}$ and estimations of the contact and weightbearing areas of this joint ${ }^{21}$, the points of maximum density in the lateral region of the articular facet can be interpreted as the expression of a relatively frequent participation of the contact areas under high pressure, the density pattern being a function of the stress which develops in various parts of the joint.

The interpretation of such methods when used on patients must, of course, take into account the fact that it is not so much the severity as the duration of the abnormal load which brings about abnormal distribution of the subchondral bone density ${ }^{16}$. In this connection Pauwels ${ }^{23,24}$ has spoken of the long-term action of the effective stress, which alone can lead to changes in the adaptive reaction of the tissue. Frost $\mathrm{t}^{25}$ has expressed the view that 'typical peak' loads or strains mean that mechanically controlled architectural adaptations probably fit the needs of the largest daily repeated dynamic loads and strains, rather than the needs of frequent and small, or single or rare large ones. The implication is that the living skeleton can somehow monitor its loading history and adapt its architecture to some function of that history, rather than to rare or one-time events. These ideas, some having originated during $1963-5^{26-31}$ are supported by considerable evidence today, and many other authorities concur ${ }^{32-36}$ even though they still await hard evidence.

In our opinion, CT- osteoabsorptiometry constitutes a valuable addition to the basic research underlying clinical diagnosis in the patient.

\section{References}

1 Pauwels F. Über die Verteilung der Spongiosadichte im coxalen Femurende und ihre Bedeutung für die Lehre vom funktionellen Bau des menschlichen Knochens. 7.Beitrag zur funktionellen Anatomie und kausalen Morphologie des Stütz-apparates. Morph Jb 1955; 95: 35-54

2 Pauwels F. Die Druckverteilung im Ellbogengelenk, nebst grundsätzlichen bemerkungen über den gelenkdruck. 11.Beitrag zur funktionellen Anatomie und kausalen Morphologie des Stützapparates. Z Anat Entw-gesch 1963; 123: 643-67

3 Kummer B. Funktioneller Bau und funktionelle Anpassung des Knockens. Anat Anz 1962; 111: 261-93

4 Knief J-J. Quantitative Untersuchung der Verteilung der Hartsubstanzen im Knochen und ihrer Beziehung zur lokalen mechanischen Beanspruchung. Z Anat Entwgesch 1967; 126: 55-80

5 Knief J-J. Materialverteilung und beanspruchungsverteilung im coxalen Femurendedensitometrische und spannungsoptische Untersuchungen. Z Anat Entw-gesch 1967; 126: 81-116

6 Schmitt HP. Uber die Beziehung zwischen Dichte und Festigkeit des Knochens am Beispiel des menschlichen Femur. Z Anat Entw-gesch 1968; 127: 1-24

7 Amtmann E Schmitt HP. Über die Verteilung der Corticalisdichte im menschlichen Femurschaft und ihre Bedeutung für die Bestimmung der Knochenfestigkeit. $Z$ Anat Entw-gesch 1968; 127: 25-41

8 Amtmann E. Mechanical stress, functional adaption and the variation-structure of the femur diaphysis. Ergebn Anat Entw-gesch Bd. Berlin: Springer-Verlag, 1971; 44: Heft 3

9 Konermann H. Dichteverteilung im Röntgenbild des Skeletts. Naturwissenschaften 1970; 57: 255

10 Konermann H. Quantitative Bestimmung der Materialverteilung nach Röntgenbildern des Knochens mit einer neuen photographischen Methode. $Z$ Anat 1971; 134: 13-48

11 Schleicher A, Tillmann B, Zilles K. Quantitative analysis of $\mathrm{X}$-ray images with a television image analyser. Microscopia Acta 1980; 83: 189-96

12 Müller-Gerbl M, Putz R, Hodapp N, Schulte E, Wimmer B. Computed tomography-osteoabsorptiometry for assessing the density distribution of subchondral bone as a measure of long-term mechanical adaptation in individual joints. Skeletal Radiol 1989; 18: 507-12

13 Tillmann B. Die Beanspruchung des menschlichen Hüftgelenks. III.Die form der facies lunata. Z Anat Entwgesch 1969; 128: 329-49

14 Tillmann B. Die Beanspruchung des menschlichen Ellbogengelenks. 1.Funktionelle Morphologie der Gelenk-flächen. Z Anat Entw-gesch 1971; 134: 328-42

15 Tillmann B. Entwicklung und funktionelle Anatomie des Ellbogengelenkes. Z Orthop 1978; 116: 392-400

16 Tillmann B. A contribution to the functional morphology of articular surfaces. In: Bargmann W, Doern W, eds. Normale und pathologische Anatomie. Stuttgart: Georg Thieme Verlag, 1978: 34

17 Oberländer W. Die Beanspruchung des menschlichen Hüftgelenks. 5. Die Verteilung der Knochendichte im acetabulum. Z Anat Entw-gesch 1973; 140: 367-84

18 Müller-Gerbl M, Schulte E, Putz R. The morphological equivalents of stress in normal and diseased shoulder joints. 6th Meeting Eur Soc Biomcch, Bristol, 1988

19 Cann CE. Quantitative CT for determination of bone mineral density: a review. Radiology 1988; 509-22

20 Brade H, Tillmann B. Untersuchungen zur Form und Funktion der Patella. Verh Anat Ges 1980; 74: 829-31

21 Hehne HJ. Das Patellofemoralgelenk. Stuttgart: Enke, 1983

22 Maquet PGJ. Biomechanics of the knee. New York: Springer, 1976

23 Pauwels F. Gesammelte Abhandlungen zur Biomechanik des Bewegungsapparates. New York: Springer, 1965 
24 Pauwels F. Biomechanics of the locomotor apparatus. Berlin: Springer, 1980

25 Frost HM. Vital biomechanics: proposed general concepts for skeletal adaptations for mechanical usage. Calcif Tissue Int 1988; 145-56

26 Frost HM. An introduction to biomechanics. Springfield: Charles C Thomas, 1963

27 Frost HM. The laws of bone structure. Springfield: Charles C Thomas, 1964

28 Frost HM. A chondral modelling theory. Calcif Tissue Int 1979; 28: 181-200

29 Frost HM. Mechanical determinants of bone modelling. J Met Bone Dis Rel Res 1983; 4: 217-30

30 Frost HM. Intermediary organization of the skeleton. Boca Raton: CRC Press, 1986; I-II
31 Epker BN, Frost HM. Correlation of patterns of bone resorption and formation with physical behaviour of loaded bone. J Dent Res 1965; 44: 33-42

32 Cowin SC. Mechanical modelling of the stress adaptation process in bone. Calcif Tissue Int 1984; 36 Suppl.: S98-103

33 Currey JD. The mechanical adaptations of bones. Princeton: Princeton University Press, 1984

34 Rubin CT. Skeletal strain and the functional significance of bone architecture. Calcif Tissue Int 1984; 36: S11-8

35 Lanyon LE. Functional strain as a determinant for bone remodelling. Calcif Tissue Int 1984; 36 Suppl.: S56-61

36 Carter ER. Mechanical loading histories and cortical bone remodelling. Calcif Tissue Int 1984; 36 Suppl.: S19-24

\section{THE VOLVO AWARDS FOR LOW BACK PAIN RESEARCH 1991}

To encourage research in low back pain, the Volvo Company of Göteborg, Sweden, also this year has sponsored three prizes of US\$9000 each. Awards will be made competitively on the basis of scientific merit in one or more of the following three areas:

1. Clinical studies.

2. Bioengineering studies.

3. Studies in other basic science areas.

Papers submitted for the contest must contain original material, not previously published or submitted for publication. A multiple authorship is acceptable. The manuscripts should be in the form of a complete report, including original illustrations, not exceeding 30 typewritten pages, double-spaced, and in a form suitable for submission to a scientific journal. One original and 5 copies of each paper submitted in full should reach the address given below not later than the 30th November 1990.

One of the authors should be prepared, at his own expense, to come to Heidelberg, FRG, at the time of the meeting of the International Society for the Study of the Lumbar Spine, May 13-16, 1991, to present the paper and to receive the award.

The board of referees will be chaired by the undersigned and will contain members from the fields of clinical medicine, bioengineering and biochemistry.

Please direct all correspondance to:

Professor Alf Nachemson,

Department of Orthopaedics,

Sahlgren Hospital,

S-143 45 Göteborg, Sweden 